\title{
Oridonin-induced apoptosis in SW620 human colorectal adenocarcinoma cells
}

\author{
ZHE JI $^{1,2}$, QINGJIU TANG ${ }^{1}$, JINSONG ZHANG ${ }^{1}$, YAN YANG ${ }^{1}$, YANFANG LIU ${ }^{1}$ and YINGJIE PAN ${ }^{3}$ \\ ${ }^{1}$ National Engineering Research Center of Edible Fungi; Key Laboratory of Applied Mycological Resources \\ and Utilization, Ministry of Agriculture; Shanghai Key Laboratory of Agricultural Genetics and Breeding; \\ Institute of Edible Fungi, Shanghai Academy of Agricultural Sciences, Shanghai 201106; ${ }^{2}$ Key Laboratory of \\ Nutrition and Metabolism, Institute for Nutritional Sciences, Shanghai Institutes for Biological Sciences, Chinese \\ Academy of Sciences, Shanghai, 200031; ${ }^{3}$ Shanghai Fisheries University, Shanghai 200090, P.R. China
}

Received March 12, 2011; Accepted August 15, 2011

DOI: $10.3892 / \mathrm{ol} .2011 .408$

\begin{abstract}
Oridonin, a diterpenoid isolated from Rabdosia rubescens (Hemsl.) Hara, inhibited the growth of human tumor cell lines SW620 (colon), MCF-7 (breast) and K562 (bone marrow), and induced significant levels of apoptosis in SW620. Morphological changes indicative of cell apoptosis were observed after the cells were exposed to oridonin for $24 \mathrm{~h}$. Growth inhibition was associated with G1 phase arrest, and with time- and dose-dependent increases in caspase- 3 activity. We therefore conclude that oridonin inhibits the proliferation of SW620 cells by induction of apoptosis via the activation of caspase-3. Our data suggest that oridonin may have significant potential as an anti-colorectal adenocarcinoma agent.
\end{abstract}

\section{Introduction}

Colorectal cancer is a common cause of mortality among cancer patients worldwide. Over $9 \%$ of all cancers in males and approximately $10 \%$ of all cancers in females worldwide are colorectal cancers. In developed countries the incidence may be as high as $12-14 \%$ of all cancers, and in non-developed countries much lower rates of $7-8 \%$ of all cancers are diagnosed. Colorectal cancer is the third most common type of cancer diagnosed in the USA. Over 100,000 Americans are diagnosed with colon cancer annually and over $50 \%$ of these patients are likely to succumb to the disease.

Oridonin $\left(\mathrm{C}_{20} \mathrm{H}_{28} \mathrm{O}_{6}\right)$, an ent-kaurane diterpenoid (Fig. 1) isolated from the plant Rabdosia rubescens ( $R$. rubescens), exhibits a variety of biological properties including antitumor, anti-bacterial, oxygen free-radical scavenging and anti-mutagenic activities, and has been used for the treatment of human cancers (1-5). The compound is a chemical

Correspondence to: Dr Qingjiu Tang, Institute of Edible Fungi, Shanghai Academy of Agricultural Sciences, 2901 Beidi Road, Shanghai 201106, P.R. China

Email: jizhe2008@gmail.com

Key words: apoptosis, caspase-3, oridonin component of PC-SPES, a traditional Chinese medicinal preparation consisting of a combination of extracts from eight herbs, used with increasing frequency by prostate cancer patients worldwide (6). The effectiveness of PC-SPES in the treatment of prostate cancer has been explained in part by its complex composition, which is thought to target a number of signal transduction and metabolic pathways simultaneously, thereby eliminating the back-up or redundant mechanisms that otherwise promote cell survival when single-target agents are used (7). Among the individual herbal components of PC-SPES, $R$. rubescens has recently received much attention (8), and new studies have shown this herb to be the most potent of all PC-SPES agents in terms of inhibiting cancer growth and angiogenesis (9). A major constituent, oridonin, has been extracted and purified from $R$. rubescens, and shown to exhibit significant anti-proliferation effects on cancer cells (10).

Apoptosis is a form of cell death defined by a characteristic set of morphological and biochemical changes. Previous studies identified a role for caspases, a family of cysteinedependent aspartate-directed proteases, in apoptotic death, particularly in the context of cancer cells (11). Individual members of the caspase family mediate apoptosis in various cell types, and various caspases have been found to mediate apoptosis even within a given cell type, depending on the apoptotic stimulus received by the cells (12). Caspase-3 and caspase-9 are reported to play key roles in caspase-mediated apoptosis, and variations in their activity have been correlated to apoptosis in a wide range of cancer cells (13-14).

Oridonin has been shown to induce apoptosis of human hepatocelluar carcinoma cells (14). In the present study, the effects of oridonin on cell proliferation, cell cycle distribution and apoptosis of the colorectal adenocarcinoma cell line SW620 were assessed.

\section{Materials and methods}

Oridonin reagent. Oridonin was obtained from Shanxi Huike Botanical Development Co., Ltd., China, and shown by HPLC to be $99 \%$ pure. Stock solutions were prepared in dimethyl sulfoxide (DMSO). 


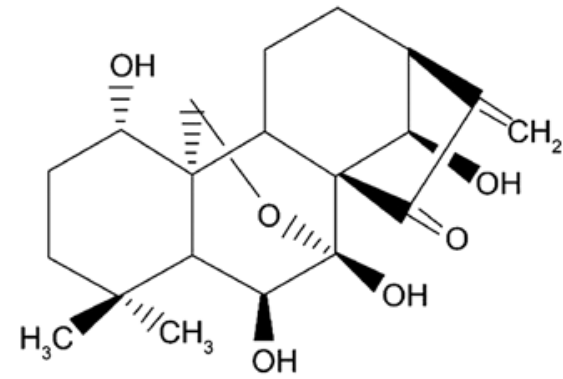

Figure 1. Chemical structure of oridonin $\left(\mathrm{C}_{20} \mathrm{H}_{28} \mathrm{O}_{6}\right)$.

Cell cultures. Human tumor cell lines SW620 cells (colon), MCF-7 (breast) and K562 (bone marrow) were obtained from the American Type Culture Collection (ATCC) and maintained at $37^{\circ} \mathrm{C}$ in RPMI-1640 containing $10 \%$ fetal calf serum (FCS) (Kraeber, Wedel, Germany), $100 \mathrm{U} / \mathrm{ml}$ penicillin and $100 \mu \mathrm{g} / \mathrm{ml}$ streptomycin.

Cell proliferation assay. Aliquots (180 $\mu \mathrm{l})$ of a cell suspension $\left(1 \times 10^{4}\right.$ cells $\left./ \mathrm{ml}\right)$ were dispensed into each well of a 96-well microplate, and $20 \mu \mathrm{l}$ of one of the different test agents (as indicated) was added. Following incubation at $37^{\circ} \mathrm{C}$ in a $5 \% \mathrm{CO}_{2}$ atmosphere for a specified time, $20 \mu \mathrm{l}$ Alamar Blue reagent (Biosource, Nivelles, Belgium) was added to each well and the incubation continued for a further $6 \mathrm{~h}$. Absorbance values at 570 and $600 \mathrm{~nm}$ were determined using a micro ELISA autoreader (Bio-Tek, Winooski, VT, USA) and cell proliferation rates were calculated according to the Biosource protocol.

Microscopic observation. Using SW620 cells cultured as described above, $1 \times 10^{6}$ cells were treated for $24 \mathrm{~h}$ with 10 , 25 and $50 \mu \mathrm{mol} / 1$ oridonin, and examined using inverted phase-contrast microscopy. Samples treated with DMSO served as controls.

Flow cytometry. To confirm the nature of the effects of oridonin on SW620 cells, dual-staining [propidium iodide (PI) and annexin $\mathrm{V}(\mathrm{AV})$ ] flow cytometry was used to measure the externalization of phosphatidylserine (PS). Aliquots $\left(5 \times 10^{6}\right)$ of SW620 cells cultured as described above were treated with 10,25 or $50 \mu \mathrm{mol} / 1$ oridonin for $24 \mathrm{~h}$. Controls were treated with DMSO only. Following washing and trypsinization, cell samples were collected by centrifugation (400 x g, $3 \mathrm{~min}, 4^{\circ} \mathrm{C}$ ) and double-stained using the apoptosis detection kit (BD Biosciences, San Jose, CA, USA) according to the manufacturer's instructions. Cells were incubated for $30 \mathrm{~min}$ at $25^{\circ} \mathrm{C}$ in $100 \mu 11 \mathrm{X}$ buffer solution, $5 \mu 1$ FITC-annexin $\mathrm{V}$ and $5 \mu \mathrm{l} \mathrm{PI}$, and a further $400 \mu \mathrm{l}$ of $1 \mathrm{X}$ solution buffer was added. The green fluorescence of annexin V-FITC-bound PS and the red fluorescence of DNA-bound PI in individual cells were measured using a BD FACSCalibur. Cell populations were classified as: $\mathrm{AV}^{-} / \mathrm{PI}^{-}$, viable cells; $\mathrm{AV}^{+} / \mathrm{PI}^{-}$, early apoptotic cells; $\mathrm{AV}^{+} / \mathrm{PI}^{+}$, apoptotic cells; and $\mathrm{AV}^{-} / \mathrm{PI}^{+}$, residual damaged cells.

Cell cycle analysis. Aliquots $\left(5 \times 10^{6}\right)$ of SW620 cells cultured as described above were treated with 25 or $50 \mu \mathrm{mol} / 1$ oridonin for $24 \mathrm{~h}$. Controls were treated with DMSO only. Following

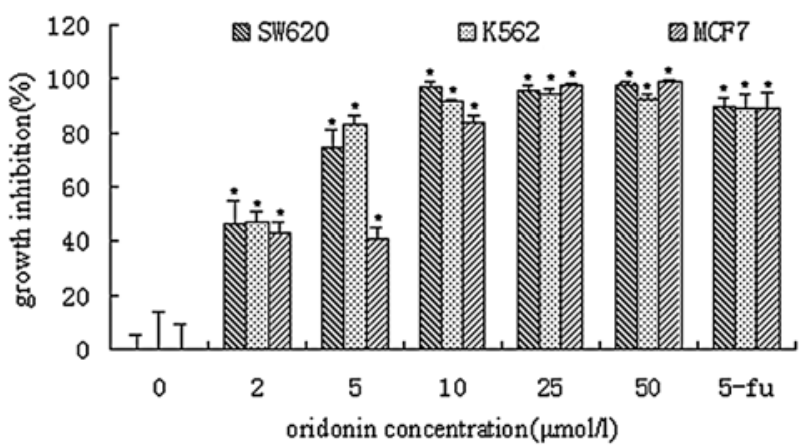

Figure 2. Effect of oridonin on the growth of different tissue cell lines. Cells (from left to right: SW620, K562, MCF7) were treated for $72 \mathrm{~h}$ with different concentrations of oridonin $(2,5,10,25$ and $50 \mu \mathrm{mol} / \mathrm{l})$ dissolved in DMSO. Negative controls were treated with DMSO only and positive controls were treated with 5 -fluorouracil $(5-\mathrm{Fu})(1 \mu \mathrm{g} / \mathrm{ml})$. Values are the mean $\pm \mathrm{SD}$ of triplicate determinations. ${ }^{*} \mathrm{P}<0.001$ (Student's t-test).

washing and trypsinization, cells were collected by centrifugation $\left(400 \mathrm{x} \mathrm{g}, 3 \mathrm{~min}, 4^{\circ} \mathrm{C}\right)$ suspended in $70 \%$ ethanol and fixed for $24 \mathrm{~h}$ at $-20^{\circ} \mathrm{C}$. Following centrifugation, the cell pellet was washed once with phosphate-buffered saline (PBS) and re-suspended in $200 \mu \mathrm{l}$ of PBS containing $500 \mu \mathrm{g} / \mathrm{ml}$ RNase A and $500 \mu \mathrm{g} / \mathrm{ml}$ PI for $50 \mathrm{~min}$ at $25^{\circ} \mathrm{C}$. Cells were then washed twice with PBS, and cellular DNA fragmentation was quantified using a FACScan analyzer.

Caspase- 3 assay. Caspase- 3 activity in lysates of SW620 cells was measured using the caspase- 3 cellular activity assay kit (Calbiochem, La Jolla, CA, USA). SW620 cells were cultured as described above and suspensions $\left(2 \times 10^{7}\right.$ cells $)$ were treated with various concentrations of oridonin $(2,5$ and $10 \mu \mathrm{mol} / \mathrm{l})$ for $24 \mathrm{~h}$. Controls were treated with DMSO only. Following washing and trypsinization, cell suspensions were centrifuged $\left(400 \mathrm{x} \mathrm{g}, 3 \mathrm{~min}, 4^{\circ} \mathrm{C}\right)$ and the cell pellets were re-suspended in $1 \mathrm{ml}$ ice-cold cell lysis buffer for $5 \mathrm{~min}$. Following centrifugation $\left(400 \mathrm{x} \mathrm{g}, 3 \mathrm{~min}, 4^{\circ} \mathrm{C}\right)$, cytosol supernatants were collected and enzyme activity was measured according to the manufacturer's instructions. Reaction mixtures (total volume $100 \mu \mathrm{l}$ ) were incubated at $37^{\circ} \mathrm{C}$ for $10 \mathrm{~min}$ and the optical density (OD) value was measured for $15 \mathrm{~h}$ at $405 \mathrm{~nm}$ using an ELISA reader.

Statistical analysis. Data are shown as the mean \pm SD of more than three separate experiments. Statistical analysis of variance and anti-proliferation of tumor cells (value of IC50) were conducted using SPSS software. $\mathrm{P}<0.05$ was considered to be statistically significant.

\section{Results}

Cell proliferation assay. Oridonin at a concentration of $2 \mu \mathrm{mol} / 1$ inhibited the growth of SW620, K562 and MCF7 cells by approximately 46, 47 and 43\%, respectively (Fig. 2). Exposure of SW620, K562 and MCF7 cells to oridonin resulted in IC50 values of 3.88, 3.74 and $5.12 \mu \mathrm{mol} / 1$, respectively. Treatment with 25 and $50 \mu \mathrm{mol} / 1$ oridonin resulted in virtually complete inhibition of cell growth, and few viable cells (see below), in all cases. Positive controls treated with 
A

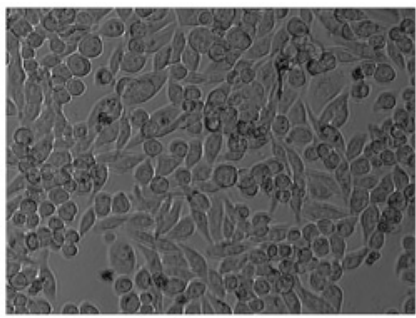

$-30 \mu \mathrm{m}$

C

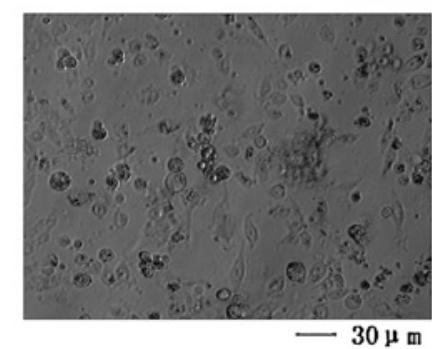

B

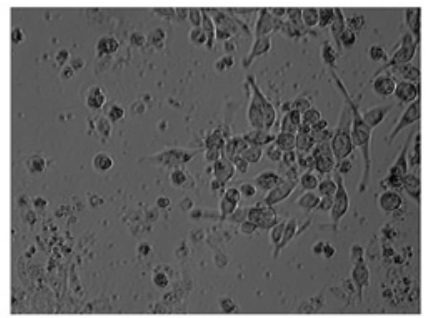

$-30 \mu \mathrm{m}$

D

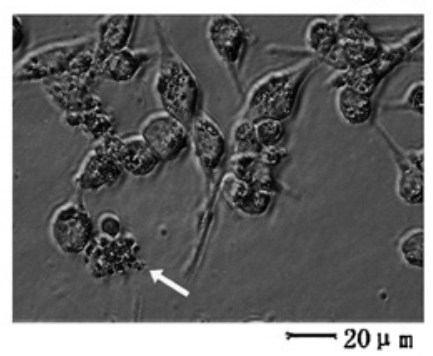

Figure 3. Photomicrographs of SW620 cells exposed to oridonin. SW620 cells were treated for $24 \mathrm{~h}$ with (A) DMSO (negative control), (B) $10 \mu \mathrm{mol} / 1 \mathrm{oridonin}$ and (C) $25 \mu \mathrm{mol} / 1$ orodonin. (D) Apoptotic cells following exposure to $10 \mu \mathrm{mol} / 1$ oridonin (magnification, x400). The arrow shows apoptotic bodies. Cell images were captured using an Olympus CKX41 inverted/phase-contrast microscope (magnification, x200).

A

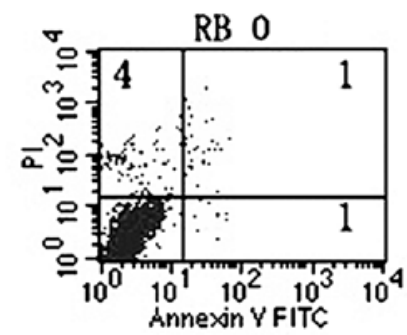

C

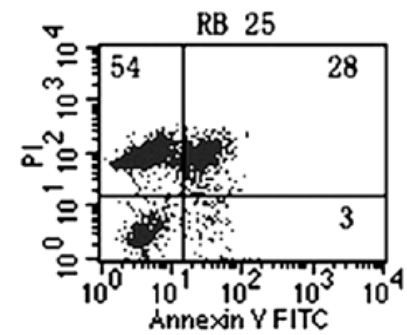

B

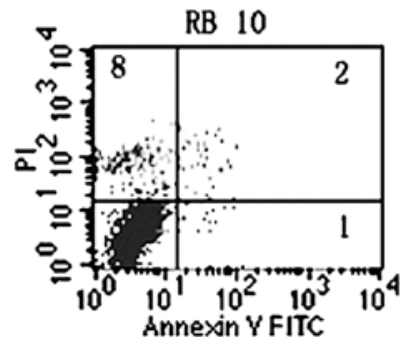

D

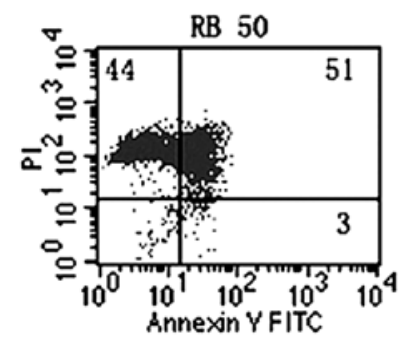

Figure 4. FACS analysis of annexin V (AV) and propidium iodide (PI) binding. SW620 cells were treated for $24 \mathrm{~h}$ with (A) DMSO (negative control), (B) $10 \mu \mathrm{mol} / 1$ oridonin, (C) $25 \mathrm{~mol} / 1$ orodonin and (D) $50 \mu \mathrm{mol} / 1$ orodonin as described in Materials and methods. PI and AV-FITC fluorescence was measured by flow cytometry and analyzed (dot-plots). Viable $\left(\mathrm{AV}^{-} / \mathrm{PI}\right)$, early apoptotic $\left(\mathrm{AV}^{+} / \mathrm{PI}\right)$, apoptotic $\left(\mathrm{AV}^{+} / \mathrm{PI}^{+}\right)$and residual damaged $\left(\mathrm{AV}^{-} / \mathrm{PI}^{+}\right)$cells are shown in the respective quadrants.

5-fluorouracil (5-Fu) were inhibited by $88-90 \%$ under these conditions.

Microscopic observation. Normally adhesive SW620 cells were readily suspended following treatment with $10 \mu \mathrm{mol} / \mathrm{l}$ oridonin, and few cells remained viable following exposure to $25 \mu \mathrm{mol} / 1$ oridonin (Fig. 3). Light microscopy revealed that cells exposed to $10 \mu \mathrm{mol} / 1$ oridonin exhibited distinct morphological features, including apoptotic bodies, associated with programmed cell death (Fig. 3D).

Flow cytometric analysis. The staining patterns of SW620 cells exposed to oridonin for $24 \mathrm{~h}$ and treated with AV-FITC and PI are shown in Fig. 4. Over 93\% of cells remained viable following treatment for $24 \mathrm{~h}$ with DMSO alone (negative control) and almost no apoptotic events were detected (Fig. 4., lower left quadrant). However, the proportion of cells with externalized PS increased in cells following treatment for $24 \mathrm{~h}$ with various concentrations of oridonin (Fig. 4).

Cell cycle analysis. To determine whether interference with cell cycle progression and induction of apoptosis mediated the oridonin-based growth inhibition of SW620 cells, the effect of oridonin on cell cycle distribution and DNA fragmentation was evaluated. Flow cytometry data indicated that treatment of SW620 cells with oridonin resulted in a decrease in the number of cells in the G2-phase of the cell cycle compared with untreated controls (Fig. 5). Oridonin at a concentration of $25 \mu \mathrm{mol} / 1$ decreased the $\mathrm{G} 2$ phase population from 15.57 to $13.45 \%$. 


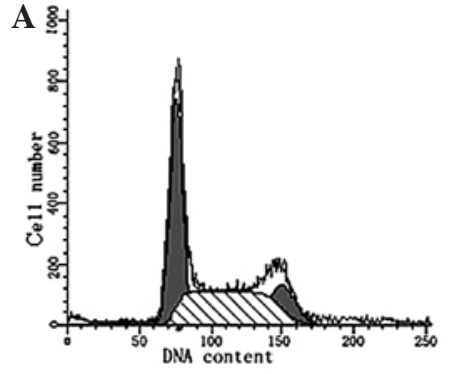

C

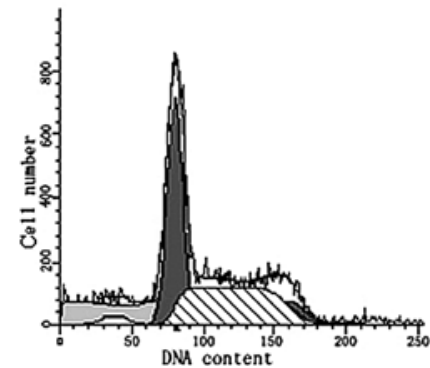

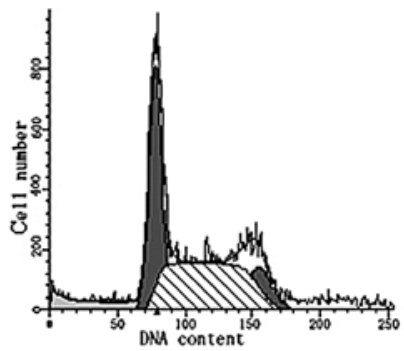

D

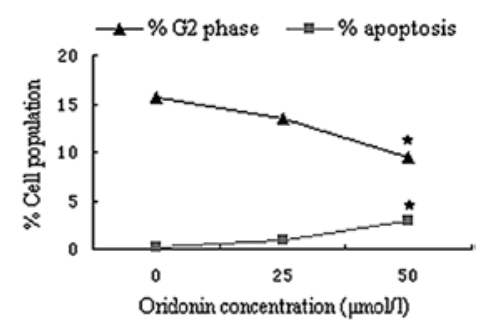

Figure 5. Inhibition of cell cycle progression in SW620 cells by oridonin. Cell cycle analysis of SW620 cells (A) without oridonin treatment, (B) with exposure to $25 \mu \mathrm{mol} / 1$ oridonin for $24 \mathrm{~h}$ and (C) exposure to $50 \mu \mathrm{mol} / 1$ oridonin for $24 \mathrm{~h}$. Cells were fixed with ethanol, stained with propidium iodide, and the cell cycle distribution analyzed by flow cytometry. Data from 10,000 cells were collected for each data file. The percentage of cells in G1, S, G2 phases and apoptotic cells were calculated using Multicycle software (D) and are indicated on the right upper side. "Significant difference between controls and oridonin-treated cells.

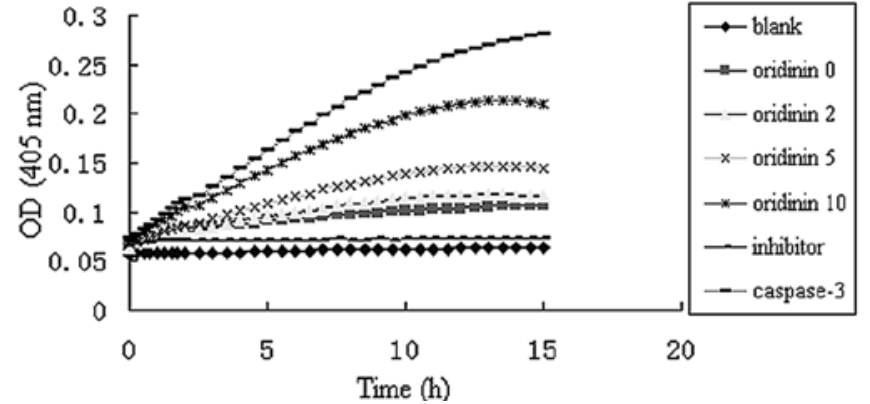

Figure 6. Effect of oridonin on caspase-3 activity in SW620 cells. SW620 cells were treated with different concentrations of oridonin $(2,5$ and $10 \mu \mathrm{mol} / \mathrm{l})$ and caspase- 3 activity was monitored. There are three negative controls: the blank well included an assay buffer only, the oridonin 0 well had DMSO-treated cell extract and the inhibitor well had an inhibitor-treated cell extract added. The positive control was purified caspase-3.

When the effect of oridonin on apoptosis was determined by measuring the number of nucleosomes in the cell cytoplasm, an increased proportion of the oridonin-treated cell population was apoptotic compared with controls.

Effect of oridonin on caspase-3 activity in SW620 cells. Caspase-3 activity was up-regulated in SW620 cells treated with various oridonin concentrations in a dose-dependent manner (Fig. 6).

\section{Discussion}

Colorectal cancer is a common cause of mortality among cancer patients worldwide. Colorectal cancer represents over $9 \%$ of all cancers in males and approximately $10 \%$ of all cancers in females worldwide. In industrialized countries the incidence of colorectal cancer may be as high as $12-14 \%$ of all cancers, and in non-industrialized countries much lower rates of $7-8 \%$ of all cancers diagnosed may be colorectal cancer. Colorectal cancer is the third most common type of cancer diagnosed in the USA. Each year over 100,000 Americans are diagnosed with colon cancer and over $50 \%$ of these patients are likely to succumb to colorectal cancer. Dysregulation of the normal colonic epithelium is the causative factor of neoplastic transformation caused by alterations in a number of properties, including epithelial cell proliferation and apoptosis. These latter two processes are highly regulated in the constantly re-generating non-transformed colonic epithelium and involve adhesion molecules, cytoskeletal proteins, cell cycle regulators and apoptosis (15).

Oridonin is a highly effective herbal derivative that has recently proven to be active against a number of different cancer cells. Cell proliferation involving multiple genetic changes plays a significant role in multistage carcinogenesis (16). Therefore, control of cell proliferation is essential for cancer prevention (17). In the present study, oridonin was found to significantly inhibit the growth of SW620, MCF-7 and K562 cells in vitro. SW620 and K562 cells showed a more favorable effect of inhibition than that of MCF-7 cells. SW620 is a colon carcinoma cell line and K562 is a leukemia cell line, and since SW620 cells are more difficult to inhibit than K562 cells, SW620 cells were selected for use in further experiments.

A V is a protein that exhibits specific affinity for PS. In non-apoptotic cells, most PS molecules are localized on the inner leaflet of the plasma membrane, but shortly after the onset of apoptosis, PS redistributes to the outer layer of the membrane (18). Cells in the early stages of apoptosis usually bind A V-FITC in the absence of PI uptake (lower right quadrant, Fig. 4), whereas those in the late stages of apoptosis bind A V-FITC and exhibit PI uptake (upper quadrant, Fig. 4).

A number of anti-cancer agents, such as halichondrin B (19) and peloruside A (20), induce cell apoptosis as a prelude 
to growth arrest, whereas other agents, such as rotenone and staurosporine A (21), induce apoptosis without cell cycle perturbation. Cell cycle analysis of oridonin-treated SW620 cells revealed an accumulation of sub-G1 cells and a decrease of G2 phase cells after $24 \mathrm{~h}$ (Fig. 5), indicating that oridonin had an apoptosis-inducing effect.

Caspases are a family of intracellular cysteine proteases with specificity for aspartic acid residues, and they play significant roles in drug-induced apoptosis in a large variety of cancer cells (22-23). Two members of this group of enzymes, known as 'initiator' and 'effector' caspases, also play a significant role in the apoptotic process (23-24). Caspase-3 is the common effector for most apoptotic pathways (13) and appears to play a particular role as a key executioner in that its active form is responsible for the cleavage and breakdown of a number of cellular components related to DNA repair and regulation. Once activated, caspase- 3 is capable of cleaving a number of essential cellular substrates, and causes membrane blebbing, disassembly of the cell structure and DNA fragmentation, which eventually lead to cell death. Certain initiator caspases, such as caspase- 9 and activate pro-caspase-3, then cleave the cellular substrates required for the orchestration of apoptosis and form a wheel of death (13,23-25). Previous data have shown that apoptosis, particularly caspase-mediated cell death, plays a significant role in the etiology, pathogenesis and therapy of a variety of human malignancies including human hepatocellular carcinoma. Additionally, the cytotoxic effects of most anti-hepatocellular carcinoma drugs are based on apoptosis induction (26). These studies indicate that the induction of apoptosis may be an index for new anti-tumor drug selection and a significant method of assessing the clinical effectiveness of numerous anti-carcinoma drugs (11).

In conclusion, this study has demonstrated that oridonin inhibits the growth of SW620 cells by inducting apoptosis via the activation of caspase-3. These findings provide a basis for further investigation of the use of oridonin in the treatment and prevention of colorectal adenocarcinoma. However, it was also found that caspase- 3 activity without oridonin and with oridonin at 2 and $5 \mu \mathrm{mol} / 1$, respectively, was similar, but at $10 \mu \mathrm{mol} / 1$ was considerably elevated. This finding is not consistent with the results obtained, in which the growth inhibition without oridonin and with oridonin at $2 \mu \mathrm{mol} / 1$, had been distinct. The results suggest that oridonin-induced apoptosis may be caspase-dependent and -independent, which may be proven by using the caspase inhibitor Z-VAD-FMK. However, further studies are required to confirm this hypothesis.

\section{Acknowledgements}

The authors thank Mr. Hengbing Shi for technical assistance, and Dr John Buswell for linguistic revision of the manuscript. This study was supported by the National Science Foundation of China (30801031 to Z. Ji) and the China Postdoctoral Science Foundation (to Z. Ji).

\section{References}

1. Fuji K, Node M, Sai M, Fujita E, Takeda S and Unemi N Terpenoids. LIII. Antitumor activity of trichorabdals and related compounds. Chem Pharm Bull (Tokyo) 37: 1472-1476, 1989.
2. Osawa K, Yasuda H, Maruyama T, Morita H, Takeya $\mathrm{K}$ and Itokawa H: Antibacterial trichorabdal diterpenes from Rabdosia trichocarpa. Phytochemistry 36: 1287-1291, 1994.

3. Zhang Y, Wang J, Lou LG, Zhang TM and Hou JW: Scavenging effect of oridonin on active oxygen free radicals. Henan Medical Research 8: 100-104, 1999.

4. Ikezoe T, Chen SS, Tong XJ, Heber D, Taguchi $\mathrm{H}$ and Koeffler HP: Oridonin induces growth inhibition and apoptosis of a variety of human cancer cells. Int J Oncol 23: 1187-1193, 2003.

5. Liu YQ, You S, Tashiro S, Onodera S and Ikejima T: Roles of Ras and extracellular signal-regulated kinase-dependent IкB $\alpha$ degradation in oridonin-enhanced phagocytosis of apoptotic cells by human macrophage-like U937 cells. Int Immunopharmacol 6: 260-268, 2006.

6. Kosty MP: PC-SPES: hope or hype? J Clin Oncol 22: 3657-3659, 2004.

7. Darzynkiewicz Z, Traganos F, Wu JM and Chen S: Chinese herbal mixture PC SPES in treatment of prostate cancer (Review). Int J Oncol 17: 729-736, 2000.

8. de la Taille A, Hayek OR, Burchardt M, Burchardt T and Katz AE: Role of herbal compounds (PC-SPES) in hormone-refractory prostate cancer: two case reports. J Altern Complement Med 6: 449-451, 2000.

9. Sartippour MR, Seeram NP, Heber D, et al: Rabdosia rubescens inhibits breast cancer growth and angiogenesis. Int J Oncol 26: 121-127, 2005.

10. Fujita E, Nagao Y, Node M, Kaneko K, Nakazawa S and Kuroda H: Antitumor activity of the Isodon diterpenoids: structural requirements for the activity. Experientia 32: 203-206, 1976.

11. Beauparlant P and Shore GC: Therapeutic activation of caspases in cancer: a question of selectivity. Curr Opin Drug Discov Devel 6: 179-187, 2003.

12. Thorburn A: Death receptor-induced cell killing. Cell Signal 16: 139-144, 2004.

13. Qi SN, Yoshida A, Wang ZR and Ueda T: GP7 can induce apoptotic DNA fragmentation of human leukemia cells through caspase-3-dependent and -independent pathways. Int J Mol Med 13: 163-167, 2004.

14. Zhang JF, Liu JJ, Liu PQ, Lin DJ, Li XD and Chen GH: Oridonin inhibits cell growth by induction of apoptosis on human hepatocelluar carcinoma BEL-7402 cells. Hepatol Res 35: 104-110, 2006.

15. Subramaniam V, Vincent IR and Jothy S: Upregulation and dephosphorylation of cofilin: modulation by CD44 variant isoform in human colon cancer cells. Exp Mol Pathol 79: 187-193, 2005.

16. Moore MA and Tsuda $\mathrm{H}$ : Chronically elevated proliferation as a risk factor for neoplasia. Eur J Cancer Prev 7: 353-385, 1998.

17. Mori H, Sugie S, Yoshimi N, Hara A and Tanaka T: Control of cell proliferation in cancer prevention. Mutat Res 428: 291-298, 1999.

18. Martin SJ, Reutelingsperger CP, McGahon AJ, et al: Early redistribution of plasma membrane phosphatidylserine is a general feature of apoptosis regardless of the initiating stimulus: inhibition by overexpression of Bcl-2 and Abl. J Exp Med 182: 1545-1556, 1995.

19. Towle MJ, Salvato KA, Budrow J, et al: In vitro and in vivo anticancer activities of synthetic macrocyclic ketone analogues of halichondrin B. Cancer Res 61: 1013-1021, 2001.

20. Hood KA, West LM, Rouwe B, et al: Peloruside A, a novel antimitotic agent with paclitaxel-like microtubule- stabilizing activity. Cancer Res 62: 3356-3360, 2002.

21. Follstad BD, Wang DI and Stephanopoulos G: Mitochondrial membrane potential differentiates cells resistant to apoptosis in hybridoma cultures. Eur J Biochem 267: 6534-6540, 2000.

22. Donepudi M and Grutter MG: Structure and zymogen activation of caspases. Biophys Chem 101-102: 145-153, 2002.

23. Denault JB and Salvesen GS: Caspases: keys in the ignition of cell death. Chem Rev 102: 4489-4500, 2002.

24. Boatright KM and Salvesen GS: Caspase activation. Biochem Soc Symp: 233-242, 2003.

25. Philchenkov AA: Caspases as regulators of apoptosis and other cell functions. Biochemistry (Mosc) 68: 365-376, 2003.

26. Huether A, Hopfner M, Sutter AP, Schuppan D and Scherubl H: Erlotinib induces cell cycle arrest and apoptosis in hepatocellular cancer cells and enhances chemosensitivity towards cytostatics. J Hepatol 43: 661-669, 2005. 